Pak. j. sci. ind. res. Ser. B: biol. sci. 2016 59(3) 133-138

\title{
Composition of Soil Seed Bank Over Cholistan Desert Microhabitats at Dingarh Fort Area, Pakistan
}

\author{
Abdul Hamid ${ }^{\text {a }}$, Muhammad Arshad ${ }^{\mathrm{a}}$, Hafiz Muhammad Zia Ullah Ghazali ${ }^{\text {b* }}$, \\ Mansoor Hameed ${ }^{c}$, Malik Muhammad Yousaf ${ }^{\mathrm{d}}$ and Mumtaz Hussain $^{\mathrm{d}}$ \\ ${ }^{\mathrm{a}}$ The Islamia University of Bahawalpur, Pakistan \\ ${ }^{b}$ Regional Agricultural Research Institute, Bahawalpur, Pakistan \\ ${ }^{\mathrm{C}}$ University of Agriculture Faisalabad, Faisalabad, Pakistan \\ ${ }^{\mathrm{d}}$ Arid Zone Research Institute (AZRI), Bahawalpur, Pakistan
}

(received May 28, 2015; revised April 12, 2016; accepted April 13, 2016)

\begin{abstract}
Soil seed banks were assessed in three soil layers (L1, from 0 to $2 \mathrm{~cm}, \mathrm{~L} 2,2$ to $4 \mathrm{~cm}$ and L3, 4 to $6 \mathrm{~cm}$ depth ) from five microhabitats i.e., Lee-ward side of sand dune (S1), Wind-ward side of sand dune (S2), Clayey area covered with sand (S3), Interdunal sandy area (S4) and Shifting sand dune of site Dingarh Fort area (S5) in Cholistan desert of Pakistan to analyse differences of soil seed bank among these habitats. Ten soil samples were collected from each microhabitat and from each layer i.e., 0-2 cm depth (L1), 2-4 cm depth (L2) and 4-6 cm depth (L3) by using $15 \times 15 \times 6 \mathrm{~cm}$ metallic sampler. Consistent differences in seed composition were observed among these microhabitats. Seedling emergence approach was used to assess the soil seed bank of Cholistan desert. Canonical correspondence analysis (CCA) was used for the soil seed bank and the plant species analysis. The microhabitats S3 (Clayey area covered with sand) and S4 (Interdunal sandy area) contributed prominently to the total variance in the species and had maximum density of seed bank and soil layer L1 contained maximum number of seeds.
\end{abstract}

Keywords: Cholistan desert, seed bank, microhabitat, canonical correspondence analysis

\section{Introduction}

Cholistan is a hot and sandy desert in South of Punjab province of Pakistan (Arshad et al., 2002). The mean annual rainfall ranges from $<100 \mathrm{~mm}$ in the West and up to $200 \mathrm{~mm}$ in the East. Rain usually occurs during monsoon (July-September) and spring (January- March). Average minimum and maximum temperature ranges between $20^{\circ} \mathrm{C}$ and $40{ }^{\circ} \mathrm{C}$, with highest soaring up to $50{ }^{\circ} \mathrm{C}$ (Arshad et al., 2002; Mughal, 1997). As annual rainfall is highly variable both on temporal and spatial scales, aridity is the most striking feature of this desert with wet and dry years occurring in clusters. Information of soil seed banks and their relationship to the standing vegetation of this area is a fundamental part of our scientific knowledge and understandings about the ecological and physiological processes through which all plants in general and desert plants in particular have become adapted to their variable and harsh environment. Although the literature related to seed banks is increasing and expanding (Mandák et al., 2012; Zuo et al., 2012; Schütz et al., 2008; Wolters and Bakker, 2002; Gul and Khan, 2001; Khan, 1993; Benoit et al., 1989; Egley, 1986) however, the present literature has no evidence about the seed bank of Cholistan desert of Pakistan. A *Author for correspondence; E-mail:ziaghazali@gmail.com major generalization of desert ecology is that the number of seeds per unit area in the soil seed bank remarkably varies among microhabitats, so far as in any desert different microhabitats can be selected for analysing the seed bank. Assessing differences in seed composition of distinct microhabitats can clarify the relationship between patterns and processes of soil seed banks. Knowledge of the particular location of different seed types may explain the spatial pattern of plant recruitment at the microhabitat scale (Marone et al., 2000). The detection of differences in composition of soil seed banks, but not of gross differences in total seed numbers, can help to identify the main ecological mechanisms which govern seed fluxes in arid and semiarid ecosystems of deserts like Choilstan. From 80 to $90 \%$ of soil seeds are present in the upper $2 \mathrm{~cm}$ of soil (AlYameniand Farraj, 1995; Reichman, 1975; Childs and Goodall, 1973) and of those, most are in the litter or top few centimeters of soil ( Bastida et al., 2010; Young and Evans, 1975). The information on how spatial scale influences the spatial heterogeneity of soil seed banks in a grassland under grazing disturbance is still lacking (Zuo et al., 2012). Same is the case with the information about the soil seed bank of Cholistan desert, although the soil seed bank is very important for conservation 
of species (Bernhardt and Elisabeth, 1989). So, the present study was under taken to observe seed bank of Cholistan desert and results of this study can provide useful information for the conservation of biodiversity of Cholistan desert.

\section{Materials and Methods}

Seed bank samplings. The present ecological piece of work was conducted at Baghdad-ul-Jadeed campus, The Islamia University of Bahawalpur, Pakistan to find out the viable seed bank for the soil samples from a selected site in Dingarh Fort area in Cholistan desert. Soil samples for seed bank were collected from three layers. They were 0-2 cm (L1), 2-4 cm (L2) and 4-6 $\mathrm{cm}$ (L3) of five microhabitats including (i) Lee-ward side of sand dune (S1), (ii) Wind-ward side of sand dune (S2), (iii) Clayey area covered with sand (S3), (iv) Interdunal sandy area (S4) and (v) shifting sand dune (S5). The field area of University campus also has sand dunes like that of Cholistan desert where temperature becomes so high in summer $\left(40-50^{\circ} \mathrm{C}\right)$ as in desert and rainfall is mostly below $200 \mathrm{~mm}$, which was ideal place for this experiment.

These samples were placed in the plastic bags and were brought to the laboratory of Cholistan Institute of Desert Studies (CIDS), The Islamia University of Bahawalpur. Samples were spread in $15 \times 15 \mathrm{~cm}$ plastic trays of $4 \mathrm{~cm}$ depth, which were made by plastic sheets molded by hand and amended to experimental trays. The required amount of water was provided regularly for seed germination to estimate the seeds viability. In the present study, the seedling emergence approach was adopted to assess the soil seed bank of Cholistan desert. Two estimation methods of soil seed bank i.e., (i) the physical extraction of seeds from the soil and (ii) emergence of seedlings, were used to estimate seed bank composition (Brown, 1992). Seedlings were identified physically and visually which were later on counted on simple numbering basis. Data was statistically analysed by using the Canoco statistical analysis programme (Braak and Šmilauer, 2002).

\section{Results and Discussion}

The interpretations of multivariate results using Canonical correspondence analysis (CCA) are straight forward and largely graphical (Palmer, 1993; Braak, 1986). The ordination diagram for Canonical correspondence analysis using the programme Canoco (Braak and Šmilauer, 2002; Braak and Prentice, 1988) was carried out on the quantitative seed bank data.

The seed bank data about Dingarh Fort area indicates that the seed of most of the species were present in the centre for all the four axis with the exception of Acacia nilotica present on the extreme left of the diagram nearer

Table 1. Weighed (weight $=$ sample total) correlation matrix of ordination axis, seed bank and environmental variables Dingarh Fort area (DGA)

\begin{tabular}{|c|c|c|c|c|c|c|c|c|}
\hline SPEC AX1 & 1.0000 & - & - & - & - & - & - & - \\
\hline SPEC AX2 & 0.0591 & 1.0000 & - & - & - & - & - & - \\
\hline SPEC AX3 & -0.1536 & -0.0128 & 1.0000 & - & - & - & - & - \\
\hline SPEC AX4 & -0.0994 & -0.0698 & 0.0628 & 1.0000 & - & - & - & - \\
\hline ENVI AX1 & 0.9000 & 0.0000 & 0.0000 & 0.0000 & 1.0000 & - & - & - \\
\hline ENVI AX2 & 0.0000 & 0.9431 & 0.0000 & 0.0000 & 0.0000 & 1.0000 & - & - \\
\hline ENVI AX3 & 0.0000 & 0.0000 & 0.8386 & 0.0000 & 0.0000 & 0.0000 & 1.0000 & - \\
\hline ENVI AX4 & 0.0000 & 0.0000 & 0.0000 & 0.9129 & 0.0000 & 0.0000 & 0.0000 & 1.0000 \\
\hline S1 & 0.1549 & -0.1418 & -0.3947 & 0.6840 & 0.1721 & -0.1504 & -0.4707 & 0.7493 \\
\hline S2 & 0.7915 & 0.1139 & -0.0938 & -0.2603 & 0.8795 & 0.1208 & -0.1119 & -0.2851 \\
\hline S3 & -0.4668 & 0.5694 & 0.2098 & -0.2406 & -0.5187 & 0.6038 & 0.2502 & -0.2636 \\
\hline S4 & -0.1199 & -0.4586 & -0.3065 & -0.3462 & -0.1332 & -0.4863 & -0.3655 & -0.3793 \\
\hline S5 & 0.2364 & -0.2545 & 0.7046 & 0.1465 & 0.2627 & -0.2698 & 0.8403 & 0.1605 \\
\hline L1 & -0.1159 & -0.6378 & 0.0042 & -0.3060 & -0.1288 & -0.6763 & 0.0050 & -0.3352 \\
\hline L2 & 0.0170 & 0.2033 & 0.0518 & 0.4504 & 0.0189 & 0.2156 & 0.0617 & 0.4934 \\
\hline \multirow[t]{3}{*}{ L3 } & 0.1546 & 0.7093 & -0.0731 & -0.1139 & 0.1718 & 0.7521 & -0.0871 & -0.1248 \\
\hline & SPEC & SPEC & SPEC & SPEC & ENVI & ENVI & ENVI & E N V I \\
\hline & AX1 & $\mathrm{AX} 2$ & $\mathrm{AX} 3$ & AX4 & AX1 & $\mathrm{AX} 2$ & AX3 & AX4 \\
\hline
\end{tabular}


Table 2. Weighed correlation matrix of environmental variables (microhabitats and soil depth) of seed bank, Dingarh Fort area, (DGA)

\begin{tabular}{lllllllll}
\hline \hline S1 & 1.0000 & - & - & - & - & - & - & - \\
S2 & -0.1001 & 1.0000 & - & - & - & - & - & - \\
S3 & -0.4790 & -0.2017 & 1.0000 & - & - & - & - & - \\
S4 & -0.2413 & -0.1016 & -0.4859 & 1.0000 & - & - & - & - \\
S5 & -0.1436 & -0.0605 & -0.2892 & -0.1457 & 1.0000 & - & - & - \\
L1 & 0.0554 & -0.1106 & -0.0810 & 0.0613 & 0.0596 & 1.0000 & - & - \\
L2 & -0.0277 & 0.0696 & 0.0139 & 0.0068 & -0.0459 & -0.7590 & 1.0000 & - \\
L3 & -0.0486 & 0.0788 & 0.1055 & -0.1020 & -0.0316 & -0.5453 & -0.1318 & 1.0000 \\
& S1 & S2 & S3 & S4 & S5 & L1 & L2 & L3 \\
\hline \hline
\end{tabular}

Table 3. Eigenvalues and cumulative percentage variances of seed bank, Dingarh Fort area

\begin{tabular}{lllllllll}
\hline \hline Axes & 1 & 2 & 3 & 4 & Total inertia & Axes & 1 & 2 \\
\hline S1 & 1.0000 & - & - & - & - & - & - & - \\
S2 & -0.1001 & 1.0000 & - & - & - & - & - & - \\
S3 & -0.4790 & -0.2017 & 1.0000 & - & - & - & - & - \\
S4 & -0.2413 & -0.1016 & -0.4859 & 1.0000 & - & - & - & - \\
S5 & -0.1436 & -0.0605 & -0.2892 & -0.1457 & 1.0000 & - & - & - \\
L1 & 0.0554 & -0.1106 & -0.0810 & 0.0613 & 0.0596 & 1.0000 & - & - \\
L2 & -0.0277 & 0.0696 & 0.0139 & 0.0068 & -0.0459 & -0.7590 & 1.0000 & - \\
L3 & -0.0486 & 0.0788 & 0.1055 & -0.1020 & -0.0316 & -0.5453 & -0.1318 & 1.0000 \\
& S1 & S2 & S3 & S4 & S5 & L1 & L2 & L3 \\
\hline \hline
\end{tabular}

to axis1 i.e., the environmental variable (microhabitat) S2 (Wind-ward side of sand dune). Spearmans correlation coefficients of this data presented in Table 1-2, show relationship among ordination axis, seed bank of species and the environmental variables. The Eigenvalues for species-environment correlations were $0.90,0.94,0.84$, 0.91 for axis 1 to axis 4 , respectively (Table 3 ).

Here at this site the total number of species in seed bank were 19 , out of which 12 were annuals with 7 perennials. Among the 12 annuals, 3 were grasses while there were 3 perennial grasses among the 7 perennials. The total inertia (total variance in the species data) was recorded as 0.98 (Table 3). Out of the total five microhabitats involved in this analysis, only two, S3 (Clayey area covered with sand) and S4 (Interdunal sandy area) contributed prominently to the total variance in the species data while out of the three layers of soil, only L1 ( $0-2 \mathrm{~cm}$ depth) contributed the maximum to total species variance. The strong differences in the soil seed bank composition among these microhabitats, and three surface layers, studied at this site depicted by weighed means (0.49), standard deviation (0.50), and
Inflation factor (3.66). The maximum values for $\mathrm{S} 3$ (Clayey area covered with sand) and these three characters were also highest for L1 (0-2 cm depth) i.e., 0.76, 0.43 and 2.42, respectively (Table 4).

The species Cenchrus biflorus, Cenchrus ciliaris, Aristida funiculata, Tribulus longipetalus, Mollugo cerviana, Indigofera hocstetteri, Euphorbia prostrata, Gisekia pharnaceoides, Dipterygium gluacum, Capparis decidua, Calligonum polygonoides and Ochthochloa compressa were found much associated to $\mathrm{S} 3$ and the soil layer L1, as they had maximum number of seeds. The weakest association was exhibited by environmental variable S5 and soil layer L3 having the minimum species in soil seed bank with lowest number of seeds as shown in the ordination diagram (Fig.1).

Seed bank. Indigenous soil seed banks play a very important role in facilitating the natural vegetation particularly in the deserts where the environmental conditions are too harsh and recovery of vegetation after a long dry spell mainly depends on the soil seed banks. Desert ecosystems rely heavily on the remaining soil seed bank as a reservoir of plant propagules. The 
Table 4. (Weighed) mean, standard deviation and inflation factor, Dingarh Fort area (DGA)

\begin{tabular}{llll}
\hline \hline Name & $\begin{array}{l}\text { Mean } \\
\text { (weighed) }\end{array}$ & $\begin{array}{l}\text { Stand. } \\
\text { dev. }\end{array}$ & $\begin{array}{l}\text { Inflation } \\
\text { factor }\end{array}$ \\
\hline SPEC AX1 & 0.0000 & 1.1112 & - \\
SPEC AX2 & 0.0000 & 1.0603 & - \\
SPEC AX3 & 0.0000 & 1.1925 & - \\
SPEC AX4 & 0.0000 & 1.0954 & - \\
ENVI AX1 & 0.0000 & 1.0000 & - \\
ENVI AX2 & 0.0000 & 1.0000 & - \\
ENVI AX3 & 0.0000 & 1.0000 & - \\
ENVI AX4 & 0.0000 & 1.0000 & - \\
S1 & 0.1921 & 0.3940 & 2.7552 \\
S2 & 0.0404 & 0.1970 & 1.4684 \\
S3 & 0.4910 & 0.4999 & 3.6639 \\
S4 & 0.1966 & 0.3974 & 2.7890 \\
S5 & 0.0798 & 0.2709 & 0.0000 \\
L1 & 0.7584 & 0.4280 & 2.4211 \\
L2 & 0.1551 & 0.3620 & 2.3808 \\
L3 & 0.0865 & 0.2811 & 0.0000 \\
\hline \hline
\end{tabular}

goal of this study was to determine the size of the soil seed bank and distribution of the seeds at different depths in five different microhabitats of site Dingarh Fort area in Cholistan desert. There are two main ways to estimate the soil seed bank. The physical extraction of seeds from the soil and emergence of seedlings from soil are used to estimate seed bank composition (Brown, 1992). In present study the seedling emergence approach was used to assess the soil seed bank of Cholistan desert.

Canonical correspondence ordination of seed bank at Dingarh Fort area (CCA seed bank data) showed that ephemerals (annuals) have large amount of seeds in the soil seed bank both as number of seeds per species and total number of species. These results are in conformity with the findings of Caballero et al. (2003) and Bertiller (1998), who described high number of species (68), in the seed bank being most of them annual gypsophytes and perennials play a secondary role here. Annual species were dominant, both in number and density. These results also match seed banks in arid ecosystems studied by Gutierrez et al. (2000), Lyaruu and Backeus (1999); Marone et al. (1998); Moro et al. (1997) and Coffen and Lauenroth (1989).

In this study, the soil seed bank of 19 species was observed in Dingarh Fort area, which comprises of mainly annuals and perennials and only one tree species (Fig. 2) (Schutz et al., 2008; Coffin and Lauenroth, 1989). Among the five microhabitats of Dingarh Fort

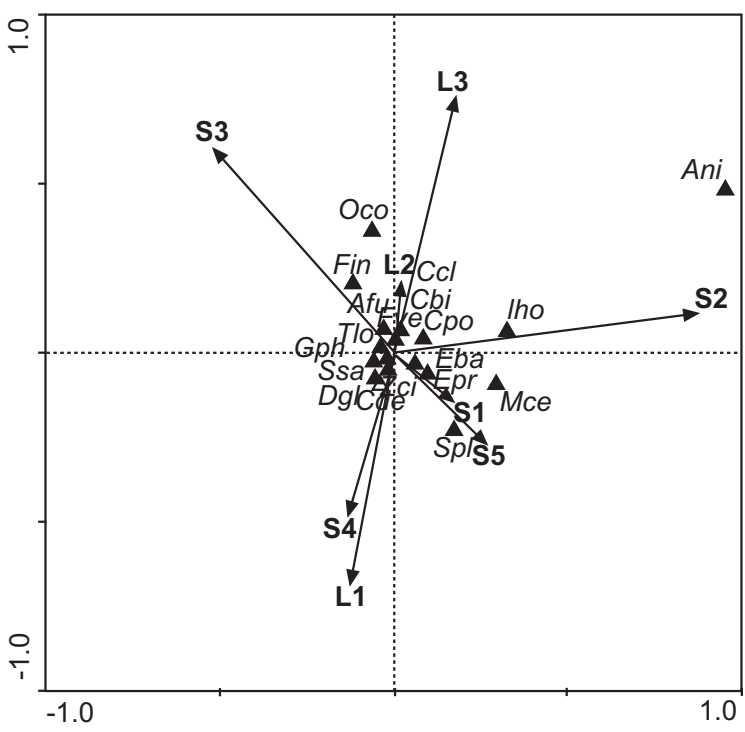

Fig. 1. Canonical correspondence ordination of seed bank at site Dingarh Fort area (CCA seed bank data) showing the relationships between species (triangles) and environmental variables (arrows) Eragrostis barreliri $=$ Eba,Ochthochloa compressa $=\mathrm{Oco}$; Cenchrus biflorus =Cbi; Cenchrus ciliaris $=\mathrm{Cci}$; Aristida funiculata $=\mathrm{Afu}$; Tribulus longipetalus $=$ Tlo; Sasuvium sasuvioides $=$ Ssa; Mollugo cerviana $=$ Mce; Indigofera hocstetteri $=$ Iho; Gisekia pharnaceoides $=$ Gph; Euphorbia prostrata=Epr, Foeniculum velgarus $=\mathrm{Fve}$; Dipterygium gluacum $=\mathrm{Dgl}$; Capparis decidua $=\mathrm{Cde} ;$ Calligonum polygonoides $=\mathrm{Cpo}$; Acacia nilotica $=\mathrm{Ani}$; Fagonia cretica $=$ Fin, Stipagrostis plumosa= Spl. The environmental variables (vectors) (microhabitats) $=\mathrm{S} 1$; $($ Lee-ward side of sand dune) S2 (Wind-word side of sand dune), S3 (Clayey area covered with sand) $=\mathrm{S} 4$ (Interdunal sandy area) $=$ S5 (Shifting sand dune $)$ and three soil layers $=\mathrm{L} 1(0-2 \mathrm{~cm}$ depth); $\mathrm{L} 2=(2$ to $4 \mathrm{~cm}) ; \mathrm{L} 3=(4-6 \mathrm{~cm})$.

area the microhabitats S3 (Clayey area covered with sand) and S4 (Interdunal sandy area) contributed prominently to the total variance in the species and have maximum seed bank and soil layer L1 (0-2 cm depth) contained the maximum number of seeds as observed by Al-Yemeni and Ferraj (1995) that maximum emergence of seedlings form upper most $(0-2 \mathrm{~cm})$ layer of the soil. Also many other observations on the vertical distribution of the seed bank confirmed literature reports that the majority of seeds are located in the top layer of the soil (Gul and Khan, 2001; Marone et al., 1998; Connor and Pickett, 1992). 


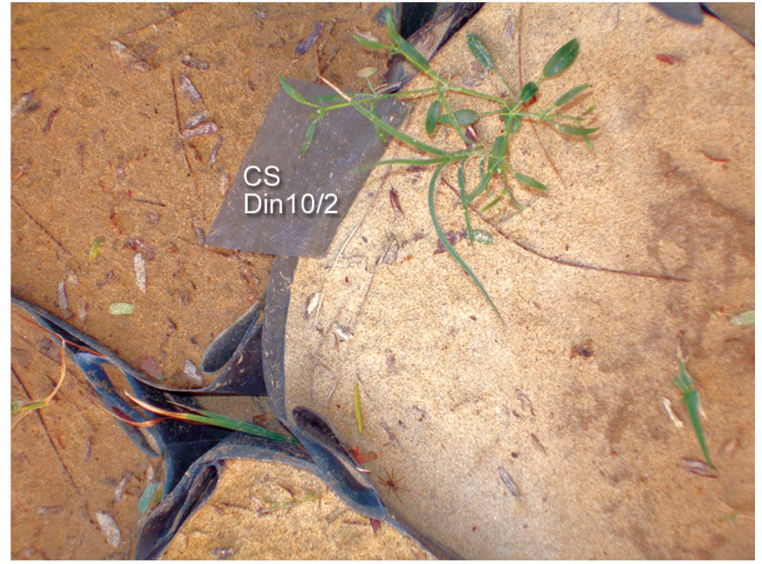

Fig. 2. Plastic sheets molded and amended to experimental trays, showing the germination of seedlings of Acacia nilotica (tree) and Cenchrus ciliaris (grass). Picture shows the successful vegetative survival of both types of seedlings, three weeks after their germination.

The weakest association was exhibited by microhabitat S5 (Shifting sand dune) and soil layer L3 (4-6 cm) having the minimum species in soil seed bank with lowest number of seeds. Ma et al. (2006) reported that microhabitat and stand age of sand have effects on soil seed viability and seedling development. They found that three species, namely; Artemisia ordosica, Caragana korshinskii and Hedysarum scoparium exhibited significantly different number of viable seeds in soils from differently aged stands. So according to these findings shifting sand dunes are formed by the moving sand which has very short age so it contained very low soil seed bank, as depicted by the results of this study.

\section{Conclusion}

The number of species and emerging seedlings in the soil seed banks were higher in the soil of microhabitat Clayey area covered with sand followed by the microhabitat Interdunal sandy area and Shifting sand dune microhabitat had very low soil seed bank. Among the three soil layers L1(0-2 cm) had maximum soil seed bank as compared to the deeper layers. So from the above results, it is concluded that different microhabitats had variable soil seed bank and the maximum seed density could occur and prevail in the surface layer of the soil up to $2 \mathrm{~cm}$ depth.

\section{Acknowledgement}

We acknowledge Major Tahir for providing luggage support in sample collections and Prof. Dr. Muhammad
Mukhtar, Vice Chancellor, The Islamia University of Bahawalpur, for his fruitful facilitation by providing computer and canoco programme, during the course of investigations.

\section{References}

Al-Yameni, M.N., Al- Farraj, M.M. 1995. The seed bank of desert soil in central Saudi Arabia. Pakistan Journal of Botany, 27: 309-319.

Arshad, M., Salah-ud-Din, Rao, A.R. 2002. Phytosociological assessment of natural reserve of National Park Lalsuhanra (Punjab, Pakistan). Asian Journal of Plant Science, 1: 174-175.

Bastida, F., Gonzalez-Andujar, J.L., Monteagudo, F.J., Menendez, J. 2010. Aerial seed bank dynamics and seedling emergence patterns in two annual Mediterranean Asteraceae. Journal of Vegetation Science, 21: 541-550.

Benoit, D.L., Kenkel, N.C., Cavers, P.B. 1989. Factors influencing the precision of soil seed bank estimates. Canadian Journal of Botany, 67: 2833-2840.

Bernhardt, K.G., Elisabeth, U. 1989. The importance of soil seed banks for the conservation of nearly extinct species: insights from Coleanthus subtilis (Poaceae). Weed Research, 29: 247-254.

Bertiller, M.B. 1998, Spatial patterns of the germinable soil seed bank in northern Patagonia. Seed Science Research, 8: 39-45.

Braak, C.J.F. ter., Šmilauer, P. 2002. Canoco Reference Manual and Cano Draw for Windows User's Guide: Software for Canonical Community Ordination (version 4.5), Ithaca, NY, USA. www.canoco.com: (Microcomputer Power).

Braak, C.J.F.ter., Prentice, I.C. 1988. A theory of gradient analysis. Advances in Ecological Research, 18: 272-313.

Braak, C.J.F.ter. 1986. Canonical correspondence analysis, a new eigenvector technique for multivariate direct gradient analysis. Ecology, 67: 1167-1179.

Brown, D. 1992. Estimating the composition of a forest seed bank, a comparison of the seed extraction and seedling emergence methods. Canadian Journal of Botany, 70: 1603-1612.

Caballero, I., Olano, J.M., Loidi, J., Escudero, A. 2003. Seed bank structure along a semi-arid gypsum gradient in central Spain. Journal of Arid Environment, 55: 287-299.

Childs, S., Goodall, D.W. 1973. Seed reserves of desert soils. US/IBP Desert Biome Research Memorandum, 7375.

Coffin, D.P., Lauenroth, W.K.1989. Spatial and temporal 
variation in the seed bank of a semiarid grassland. American Journal of Botany, 76: 53-58.

Connor, T.G.O., Pickett, G.A. 1992. The influence of grazing on seed production and seed banks of some African savanna grasslands. Journal of Applied Ecology, 29: 247-260.

Egley, G.H. 1986. Stimulation of weed seed germination in soil. Review of Weed Science, 2: 67-89.

Gul, D., Khan, M.A. 2001. Seasonsonal seed bank patterns of an Artnrocnemum macrostacnyum (Chenopodiaceae) community along a coastal marsh inundation gradient on the Arabian Sea near Karachi, Pakistan. Pakistan Journal of Botany, 33: 305-314.

Gutierrez, J.R., Arancio, G., Jaksic, F.M. 2000. Variation in vegetation and seed bank in a Chilean semi-arid community affected by ENSO 1997. Journal of Vegetation Science, 11: 641-648.

Khan, M.A.1993. Relationship of seed bank to plant distribution in saline arid communities. Pakistan Journal of Botany, 25: 73-82.

Lyaruu, H.V.M., Backeus, I. 1999. Soil seed bank and regeneration potential on eroded hill slopes in the Kondoa Irangi Hills, Central Tanzania. Applied Vegetation Science, 2: 209-214.

Ma, J.Y., Ren, J., Wang G., Chen, F.H. 2006. Influence of different microhabitats and stand age on viable soil seed banks of sand stabilizing species. South African Journal of Botany, 72: 46-50.

Mandák, B., Zákravský, P., Mahelka, V., Plaèková, I. 2012. Can soil seed banks serve as genetic memory. A study of three species with contrasting life history strategies. PLOS One, 7: 1-12

Marone, L., Horno, M.E., González, D.S.R. 2000. Postdispersal fate of seeds in the Monte desert of Argentina: patterns of germination in successive wet and dry years. Journal of Ecology, 88: 940-949.

Marone, L., Rossi, B.E., Horno, M.E. 1998. Timing and spatial patterning of seed dispersal and redistribution in a South American warm desert. Plant Ecology, 137: 143-150.

Moro, M.J., Pugnaire, F.I., Haase, P., Puigdefabregas, J. 1997. Mechanisms of interaction between a leguminous shrub and its understorey in a semiarid environment. Ecography, 20: 175-184.

Mughal, M.R. 1997. Ancient Cholistan, Archeology and Architecture. Ferozesons, Publishers, Pakistan.

Palmer, M.W. 1993. Putting things in even better order: the advantages of canonical correspondence analysis. Ecology, 74: 2215-2230.

Reichman, O.J. 1975. Relation of desert rodent diets to available resources. Journal of Mammalogy, 56: 731-749.

Schutz, M., Kretz, C., Dekoninck, L., Iravani, M., Risch, A.C. 2008. Impact of Formica exsecta Nyl. on seed bank and vegetation patterns in a subalpine grassland ecosystem. Journal of Applied Entomology, 132: 295-305.

Wolters, M., Bakker, J.P. 2002. Soil seed bank and driftline composition along a successional gradient on a temperate salt marsh. Applied Vegetation Science, 5: 55-62.

Young, J.A., Evans, R.A. 1975. Germinability of seed reserves in a big sagebrush community. Weed Science, 23: 358-364.

Zuo, X., Wang, S., Zhao, X.Y., LI, W.J., Knops, J., Kochsiek, A. 2012. Effect of spatial scale and topography on spatial heterogeneity of soil seed banks under grazing disturbance in a sandy grassland of Horqin sandy land, northern China. Journal of Arid Land, 4: 151-160. 